\section{JURNAL PENELITIAN PENDIDIKAN IPA}

http://jurnal.unram.ac.id/index.php/jpp-ipa
e-ISSN : 2407-795X

p-ISSN : 2460-2582

Vol 2, No, 1

Januari 2016

\title{
EFEKTIFITAS BEBERAPA TANAMAN HIAS DALAM MENYERAP TIMBAL (Pb) DI UDARA
}

\author{
Baiq Mirawati ${ }^{1}$, Muhlis ${ }^{2}$, Prapti Sedijani ${ }^{3}$ \\ Mahasiswa Program Studi Magister Pendidikan IPA Universitas Mataram ${ }^{123}$ \\ E-mail: rahili_06@yahoo.com
}

\begin{abstract}
Key Words
Lead $(P b)$,

lidah mertua

(Sanseviera

trifasciata.sp

), Puring

(Codiaeum

variegatum),

Palem

Kuning

(Chrysalidoc

arpus

lutecsens).

Abstract

The objective of this reasearch was to determine the ornamental plants Lidah mertua (Sanseviera trifasciata.sp), Puring (Codiaeum variegatum), Palem Kuning (Chrysalidocarpus lutecsens) ability to absorb lead (Pb) concentration. This research is descriftive explorative research design with completely randomized design with 9 times treatments and 3 repetitions. The independent variables were lidah mertua (Sanseviera trifasciata.sp) Puring (Codiaeum variegatum), Palem Kuning (Chrysalidocarpus lutecsens), and the subjec variable is measurement of lead $(\mathrm{Pb})$ concentration in the leaves. Data analysis techniques using qualitative and quantitative analysis. Quantitative data was obtained by calculating the lead $(\mathrm{Pb})$ concentration in ornamental plants such as: Lidah mertua (Sanseviera trifasciata.sp) Puring (Codiaeum variegatum), Palem Kuning (Chrysalidocarpus lutecsens) by using AAS (Atomic Absorption Spectrophotometer) test. Based on reasearch finding, there several finding of oranamental plants ability in absorb lead $(\mathrm{Pb})$ : lidah mertua (Sanseviera trifasciata.sp ): 0,06 ppm; 0,1 ppm; 0,15 ppm, puring (Codiaeum variegatum): 0,04 ppm; 0,09 ppm; 0,2 ppm and palem kuning (Chrysalidocarpus lutecsens): 0,02 ppm; 0,04 ppm; 0,11 ppm. Statistical test states that the type of plant and the traffic density does not affect the ability of plants to absorb lead $(\mathrm{Pb})$.
\end{abstract}

\begin{tabular}{|c|c|}
\hline Kata Kunci & Abstrak \\
\hline $\begin{array}{l}\text { Timbal }(\mathrm{Pb}) \text {, } \\
\text { lidah mertua } \\
\text { (Sanseviera } \\
\text { trifasciata.sp } \\
\text { ), Puring } \\
\text { (Codiaeum } \\
\text { variegatum), } \\
\text { Palem } \\
\text { Kuning } \\
\text { (Chrysalidoc } \\
\text { arpus } \\
\text { lutecsens) }\end{array}$ & $\begin{array}{l}\text { Tujuan penelitian ini adalah untuk mengetahui kemampuan tanaman hias Lidah mertua } \\
\text { (Sanseviera trifasciata.sp), Puring (Codiaeum variegatum), Palem Kuning } \\
\text { (Chrysalidocarpus lutecsens), dalam menyerap timbal (Pb). Penelitian ini merupakan } \\
\text { penelitian deskriftif eksploratif dengan desain penelitian Rancangan Acak Lengkap } \\
\text { (RAL) dengan } 9 \text { kali perlakuan dan } 3 \text { kali pengulangan. Subjek penelitian adalah lidah } \\
\text { mertua (Sanseviera trifasciata.sp) Puring (codiaeum variegatum) dan Palem Kuning } \\
\text { (Chrysalidocarpus lutecsens), objek penelitian adalah pengukuran konsentrasi timbal (Pb) } \\
\text { pada daun. Data dianalisis secara kuantitatif dan kualitatif. Pengumpulan data kuantitatif } \\
\text { diperoleh dengan menghitung konsentrasi timbal (Pb) tanaman hias: lidah mertua } \\
\text { (Sanseviera trifasciata.sp), Puring (codiaeum variegatum) dan Palem Kuning } \\
\text { (Chrysalidocarpus lutecsens) menggunakan uji AAS (Atomic Absorption } \\
\text { Spectrophotometer). Berdasarkan penelitian diperoleh selisih kemampuan tanaman } \\
\text { menyerap timbal (Pb) sebelum dan sesudah pemaparan tanaman lidah mertua (Sanseviera } \\
\text { trifasciata.sp ): } 0,06 \mathrm{ppm} ; 0,1 \text { ppm; } 0,15 \text {, tanaman puring (codiaeum variegatum): } 0,04 \\
\text { ppm; } 0,09 \mathrm{ppm} ; 0,2 \mathrm{ppm} \text { serta tanaman palem kuning (Chrysalidocarpus lutecsens): } 0,02 \\
\text { ppm; } 0,04 \mathrm{ppm} ; 0,11 \mathrm{ppm}\end{array}$ \\
\hline
\end{tabular}




\section{PENDAHULUAN}

Pencemaran diudara mengancam kehidupan kita dan makhluk hidup lainnya. Data ISPU (Indeks Standar Pencemaran Udara), menyatakan bahwa kategori udara yang baik adalah apabila tingkat kualitas udara tidak memberikan efek buruk bagi kesehatan manusia serta tidak berpengaruh pada tumbuhan dan nilai estetika bangunan. Udara dikatakan tidak sehat, apabila kualitas udara di suatu kota secara umum dapat menimbulkan masalah kesehatan yang serius pada penduduk setempat.

Pencemaran udara di daerah perkotaan berasal dari sisa pembakaran kendaraan bermotor dan industri. Kendaraan bermotor dikelompokkan sebagai sumber pencemar yang bergerak, bahan pencemar yang diemisikan oleh kendaraan bermotor memiliki pola penyebaran spasial yang meluas.

Kendaraan bermotor menghasilkan $85 \%$ dari seluruh pencemaran udara, salah satunya adalah timbal (Jamhari, 2014). Selain timbal $(\mathrm{Pb})$, bahan pencemar yang terdapat di dalam gas buang kendaraan bermotor adalah karbon monoksida (CO), berbagai senyawa hidrokarbon, berbagai oksida nitrogen (NOx), sulfur (SOx) dan partikulat debu termasuk timbal (Tugaswati, 2011 dalam Yudha dkk 2013).
Salah satu faktor yang menyebabkan kontaminasi timbal $(\mathrm{Pb})$ pada lingkungan adalah pemakaian bensin bertimbal yang masih tinggi di Indonesia. Untuk mempermudah bensin terbakar, titik bakarnya harus diturunkan melalui peningkatan bilangan oktan dengan penambahan timbal $(\mathrm{Pb})$ dalam bentuk Tetra Ethyl Lead (TEL). Namun dalam proses pembakaran, timbal $(\mathrm{Pb})$ dilepas kembali bersama-sama sisa pembakaran lainnya ke udara (Kamal, 2008).

Timbal yang masuk ke dalam tubuh melalui saluran pernapasan atau pencernaan menyebar ke berbagai organ melalui sistem peredaran darah. Penimbunan timbal yang terjadi pada ginjal, hati, otak, saraf, dan tulang dapat berlangsung dalam jangka panjang dan dalam konsentrasi tinggi timbal dapat merusak jaringan saraf dan fungsi ginjal. Gejala keracunan kronis akibat timbal bisa menyebabkan hilangnya nafsu makan, konstipasi, sakit kepala, anemia, kelumpuhan anggota badan, kejang dan gangguan penglihatan, lebih lanjut Parewangi (2014) menyatakan bahwa timbal $(\mathrm{Pb})$ mengakibatkan sintesis haemoglobin dan kinerja system saraf pusat dan system saraf tepi.

Pendekatan untuk mereduksi kandungan partikel timbal di udara adalah dengan bioremediasi menggunakan 
tumbuhan. Menurut Hapsari dan Dewi (2012) di kawasan Rungkut Surabaya, diketahui bahwa pohon pelindung di sepanjang ruas jalan daerah perkotaan terpapar oleh timbal dalam jumlah yang tinggi.

Beberapa tanaman hias yang telah dilaporkan antara lain tanaman akasia dan pohon trembesi, serta angsana mampu menyerap $\mathrm{Pb}, \mathrm{Z}$ dan $\mathrm{Cr}$, Nilawati (2011). Pada bagian tanaman, logam $\mathrm{Pb}$ lebih banyak diserap oleh bagian daun sedangkan Zn pada bagian kulit akar. Dan faktor lain yang ikut berperan diantaranya adalah tingkat pertumbuhan pohon, jarak terhadap sumber pencemar, konsentrasi bahan pencemar, dan durasi paparan pencemar. Kehadiran beberapa jenis tanaman pada daerah-daerah padat berlalu lintas mampu yang menyerap polutan berbahaya seperti timbal tersebut sangat penting. Menurut pemaparan Dewi dan Hapsari (2012) menjelaskan bahwa sejumlah pohon berdaun lebar mampu menyerap bahanbahan pencemar udara yang dihasilkan dari kendaraan bermotor yaitu tanaman pisang hias, puring, batavia dan bugenvil. Tanaman palem sering digunakan sebagai tanaman hias di pinggir jalan, dan saat ini belum banyak dipublikasikan mengenai efektifitas tanaman palem dalam menyerap timbal di udara. Dari latar belakang di atas, perlu dilakukan penelitian mengenai
"Efektifitas Tanaman Hias dalam Menyerap Timbal $(\mathrm{Pb})$ di Udara”.

Tujuan penelitian ini adalah untuk mengetahui kemampuan tanaman lidah mertua (Sanseviera trifasciata.sp), puring (codiaeum variegatum), palem kuning (Chrysalidocarpus lutecsens) dalam menyerap timbal $(\mathrm{Pb})$ di kota mataram dengan kepadatan lalu lintas rendah, sedang hingga tinggi.

\section{METODE PENELITIAN}

Jenis penelitian yang digunakan dalam penelitian ini adalah penelitian deskriftif eksploratif. Desain penelitian ini menggunakan Rancangan Acak Lengkap (RAL) dengan 9 kali perlakuan dan 3 kali pengulangan. Subjek yang digunakan dalam penelitian ini bersifat purposive sampling, sampel yang digunakan: lidah mertua (Sanseviera trifasciata.sp), Puring (codiaeum variegatum) dan Palem Kuning (Chrysalidocarpus

lutecsens). Penggumpulan data secara kuantitatif dan kualitatif. Pengumpulan data kuantitatif diperoleh dengan cara menghitung konsentrasi timbal $(\mathrm{Pb})$ tanaman hias Lidah mertua (Sanseviera trifasciata.sp), Puring (codiaeum variegatum) dan Palem Kuning (Chrysalidocarpus lutecsens) menggunakan uji AAS (Atomic Absorption Spectrophotometer), sedangkan untuk menggumpulkan data secara kualitatif 
menggunakan deskriftif kualitatif dari hasil penggumpulan data secara kuantitatif.

\section{HASIL DAN PEMBAHASAN}

A. Deskripsi Data Kemampuan Tanaman Menyerap Timbal $(\mathrm{Pb})$

Berdasarkan hasil uji dengan metode Spektrofotometri Serapan Atom (SSA), konsentrasi timbal $(\mathrm{Pb})$ diperoleh hasil yang disajikan pada Gambar 1:
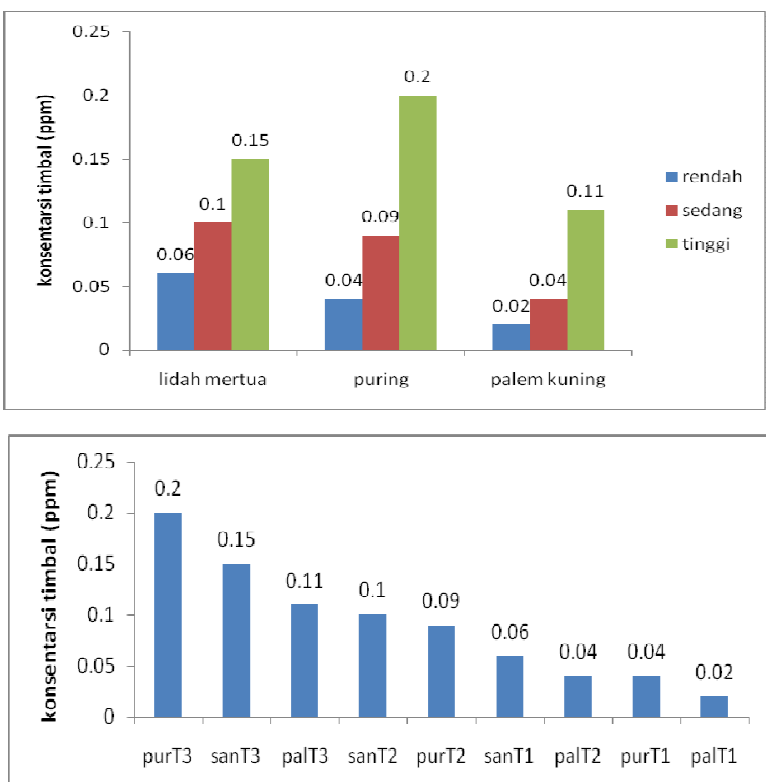

Gambar 1. Rata-rata kemampuan tanaman menyerap timbal $(\mathrm{Pb})$.

Tanaman yang digunakan lidah mertua (san), puring (pur) dan palem kuning (pal), yang dipaparkan selama 1 bulan (feb-maret 2015). Tanaman diletakkan pada jalan arus lalu lintas rendah (T1), jalan arus lalu lintas sedang (T2) dan jalan arus lalu lintas tinggi (T3).
Gambar 1 di atas menunjukkan bahwa kemampuan menyerap timbal $(\mathrm{Pb})$ tertinggi diperoleh pada tanaman puring (codiaeum variegatum) yang diletakkan pada jalan arus lalu lintas tinggi (purT3) yaitu sebesar 0,20 ppm. Dan jenis tanaman palem kuning (Chrysalidocarpus lutecsens), yang diletakkan pada jalan arus lalu lintas rendah (palT1) mempunyai kemampuan menyerap timbal $(\mathrm{Pb})$ yang terendah yaitu 0,02 ppm..

B. Pembahasan Kemampuan Tanaman Dalam Menyerap Timbal $(\mathrm{Pb})$

Berdasarkan hasil penelitian kemampuan menyerap timbal $(\mathrm{Pb})$ diantara 3 tanaman yang digunakan, tanaman puring (codiaeum variegatum) mempunyai kemampuan menyerap timbal $(\mathrm{Pb})$ paling tinggi, diikuti tanaman lidah mertua (Sanseviera trifasciata.sp) dan tanaman palem kuning (Chrysalidocarpus lutecsens), hal ini senada dengan penelitian Dewi (2012) dari empat macam tanaman yang digunakan yaitu puring, beringin, ketapang dan tanjung diperoleh hasil bahwa tanaman puring mempunyai kemampuan tertinggi menyerap timbal $(\mathrm{Pb})$. Penelitian Martuti (2013) menemukan tanaman pisang hias, tanaman hias puring, batavia dan bugenvil juga dapat direkomendasikan untuk elemen taman kota karena toleran dan cukup toleran terhadap polutan. 
Pencemaran udara mengakibatkan menurunnya pertumbuhan dan produksi tanaman serta diikuti dengan gejala yang tampak (visible symptoms). Kerusakan tanaman karena pencemaran udara berawal dari tingkat biokimia (gangguan proses fotosintesis, respirasi, serta biosintesis protein dan lemak), selanjutnya tingkat ultrastruktural (disorganisasi sel membran), kemudian tingkat sel (dinding sel, mesofil, pecahnya inti sel) dan diakhiri dengan terlihatnya gejala pada jaringan daun seperti klorosis dan nekrosis (Arico, 2010). Ketinggian tanaman terutama posisi daun dari jalan raya mempengaruhi besarnya $\mathrm{Pb}$ yang diserap. Tiap pohon mempunyai respon yang berbeda terhadap pencemar udara yang berbentuk gas atau partikel. Perbedaan tersebut tergantung jenis pohon,susunan genetik,tingkat pertumbuhan pohon, jarak terhadap sumber pencemar, konsentrasi bahan pencemar, dan lama terpapar.

Konsentarsi timbal $(\mathrm{Pb})$ di udara kota mataram yang masih diketegorikan rendah $0.0003 \mu \mathrm{g} / \mathrm{Nm}^{3}$ (BLHP, 2014). Menurut Sembiring (2010) tumbuhan yang hidup pada daerah dengan tingkat kepadatan lalulintas tinggi mengandung timbal $(\mathrm{Pb})$ lebih besar dibandingkan dengan yang hidup pada daerah dengan tingkat kepadatan lalulintas rendah. Pada penelitian ini tanaman terpapar selama 30 hari dengan pergantian kondisi cuaca yang tidak menentu. Umur tanaman yang digunakan bervariasi, tanaman palem kuning berumur 3 bulan dan tanaman puring berumur sekitar 1 tahun dan tanaman lidah mertua berumur 6 bulan hingga 1 tahun. Menurut Agustin (2012) mengemukakan jumlah $\mathrm{Pb}$ di udara dipengaruhi oleh volume atau kepadatan lalu lintas, jarak dari jalan raya, hal yang mempengaruhi konsentarsi timbal $(\mathrm{Pb})$ pada tanaman yaitu lamanya tanaman terpapar, morfologi dan fisiologi tanaman artinya keberagaman morfologi dan fisiologi mempengaruhi kemampuan dari tiap tanaman untuk menyerap timbal, musim dan umur tanaman.

\section{KESIMPULAN}

Berdasarkan hasil penelitian didapatkan beberapa kesimpulan, yaitu konsentrasi timbal $(\mathrm{Pb})$ terserap oleh tanaman hias lidah mertua (Sanseviera trifasciata.sp): 0,06 ppm ; 0.10ppm; 0,15ppm, Puring (Codiaeum variegatum):0,04 ppm; $0.09 \mathrm{ppm}$; 0.20ppm,Palem Kuning (Chrysalidocarpus lutecsens): 0,02ppm; $0.04 \mathrm{ppm} ; 0,11 \mathrm{ppm}$.

\section{DAFTAR PUSTAKA}

Arico, D., 2010, Pengaruh Adaptasi Tanaman Terhadap Udara Tercemar, http://aricothescientist.blogspot.com/. 
Diakses pada tanggal 4 April 2015, pukul 22.18 WITA

Bovi Rahadiyan Adita C. Dan Naniek Ratni J. A. R.2010. Tingkat Kemampuan Penyerapan Tanaman Hias Dalam Menurunkan Polutan Karbon Monoksida., Jurnal Ilmiah Teknik Lingkungan Vol. 4 No. 1. 201, Universitas Pembangunan Nasional "Veteran" Jawa Timur.

Dewi Yusriani Sapta dan Hapsari Indri.2012.Kajian Efektivitas Daun Puring (codiaeum variegatum) Dan Lidah Mertua (sanseviera trisfasciata) Dalam Menyerap Timbal di Udara Ambien. Jurnal Ilmiah Satya Negara Indonesia. Nomor 2 Volume 5 Desember 2012 ISSN 19795246 .Universitas Satya Negara Indonesia. Jakarta.

DeRoss Fj. (1997). Smelters and Metal Reclaimenrs. In Occupational, Industrial, and environmental toxicology. New York: Mosby-Year book.

Gita Prima Yudha, Zozy Aneloi, M.Idris. 2013. Jurnal Biologi. Universitas Andalas.Juni 2013.ISSN 2303-2162

Gomez .R. E dan Kwanchi. R. H. 1995. Ilmu Peluang dan Statistika unutk Insinyur dan Ilmuwan.Penerbit ITB. Bandung.

Gunarno. 2014. Pengaruh Pencemaran Udara Terhadap Luas Daun dan Jumlah Stomata Daun Rhoeo discolor.Tidak dipublikasikan

Goldstein BD and HM Kipen. (1994). Hematologic Disorder. In Levy and Wegman (eds): Occupational Health Recognizing and Preveting WorkRealted Diseases. 3 rd ed, United Stated of America: Little Brown and Company.
Harborne, J.B \& F.A. TomasBarberan.1991.Ecological Chemistry and Biochemistry of Plant Terpenoids. Clarendon Press.Oxford.

Hermine Stover. 1983. The Sansevieria Book, Published by Endangered Species Press 12571 Red Hili Avenue. Tustln, California 92680. First edition September.

Heyne, K. 1987. Tumbuhan Berguna Indonesia 1. Yayasan Sarana WanaJaya, Jakarta.

Jamhari, M., 2014. Hubungan Kandungan Timbal $(\mathrm{Pb})$ Di Udara Dengan $\mathrm{Pb}$ Dalam Talus Lichen Xanthoparmelia xanthofarinosa. Seminar nasional biologi VIII Pendidikan Biologi. Biologi, Sains, Lingkungan, dan Pembelajaran Menuju Pembangunan Karakter.

Kadir, A. 2008. Puring. Yogyakarta: Andi Offset.

Kusuma Arief H. 2008. Distribusi Timbal pada daun beberapa tanaman perkotaan disebabkan pencemaran udara asap kendaraan bermotor di Balitro dan Jalan Tol Jagorawi. Bogor: Institut Pertanian Bogor.

Kementrian Lingkungan Hidup. 1999. Peraturan Pemerintah No. 41 Tahun 1999 tentang Pencemaran Udara.

Nugrahani P dan Sukartiningrum. 2008. Indeks Toleransi Polusi Udara (APTI) Tanaman taman Median Jalan Kota Surabaya. Jurnal Pertanian Mapeta 10 (2): 86-92.

Nilawati. 2011. Tesis. Analisis Logam Berat $\mathrm{Pb}, \mathrm{Zn}$, Dan Cr Pada Tiga Jenis Tanaman Peneduh Pinggir Jalan Di Kota Batam Kepulauan 
Riau. Sekolah PascaSarjana. Institut Pertanian. Bogor. Bogor.

NHMRC (National Health \& Medical Research Council) (2009) NHMRC Public Statement, August 2009 Blood lead levels: Lead exposure and health effects in Australia, National Health \& Medical Research Council, 7th August 2009.

Nordberg G. (1998). Metal: Chemical Properties and Toxicity. In: Stellman $\mathrm{Jm} \quad$ (ed); Encyclopedia of Occupational Health and Safety. 4 ed. Geneva; ILO.

Rahayu, S. 2006. Pengukuran Karbon Tersimpan di Berbagai Macam Penggunaan Lahan. World Agroforestry Centre. ICRAF Southeast Asia Regional Office. Bogor.

Rinawati. D. 1991. Pengaruh Pencemaran Udara di Jalan Pramuka Jakarta terhadap Kondisi Fisik dan Struktur Anatomi daun dari Anakan Beberapa Jenis Pohon. Jurusan Konservasi Hutan, Fakultas kehutanan, IPB. Bogor.

Silitonga, R.R. 2007. Puring eksotis. Jakarta: PT Buana Ilmu Populer.

Steel, R.G.D and H.J.Torrie. 1980. Principle and Procedur of Statistic. Second Edition.M.C.Graw Hill Kogasuka.Tokyo.

Sukarto, R. 2006. Pengaruh Biodiesel Terhadap Emisi Gas Buang Mesin Diesel. Teknis Vol. 7, No.1, April 2012: 36 - 40 Available at http://eprints.undip.ac.id/25526/1/len gkap.pdf [Diakses 28 Agustus 2014].

Suhadiyah Sri, Roland A. Barkey, Elis Tambaru. 2014. Korelasi Kondisi
Daun Terhadap Kadar Pb, dan Klorofil daun Hibiscus tiliaceus dan Swietenia macrophylla King. di Kampus Universitas Hasanuddin Makassar.

Steenis.C.G.G.J, 1992. Flora Untuk Sekolah di Indonesia. Jakarta. PT.Pradnya Paramita.

WHO (World Health Organisation). 2007 Lead exposure in children www.who.int/phe/news/Lead_in_Toy s_note_060807.pdf

www.nhmrc.gov.au/files_nhmrc/file/publi cations/synopses/gp03-leadpub$\underline{\text { stmnt.pdf }}$

http://azkiyamaulida.blogspot.com/2010/01 /analisis-pada-timbalpb.html 